\title{
Ad gyldighet av avdøde legers rekvisisjoner
}

\author{
Skal apotekene kunne overprøve lovlig utstedte resepter?
}

Det er nesten makabert å oppleve at apotekene nekter å godta resepter fra en nylig avdød kollega. Allerede dagen etter begravelsen fikk jeg beskjed fra et apotek om at min kollegas resept var ugyldig til tross for at resepten var utstedt med gyldighet ett år. Resepten var skrevet ut mens han var fullt arbeidsfør og hadde i behold sin gode dømmekraft.

Det samme gjelder henvisninger til laboratorier. Fürst laboratorium mente at en henvisning for å måle INR-verdiene ikke lenger var gyldig og ble avvist fordi legen var død. På den annen side var det intet i veien for å få utført prøven hvis man betalte fullt honorar!

Når leger skriver ut resepter i tiden mens de har gyldig lisens, kan man oppleve at apotekene nekter å ekspedere reseptene hvis legen på et senere tidspunkt ikke fornyer sin lisens. Selv om en forskriftsmessig fornyelse er innvilget, vil apotekene i noen tilfel- ler nekte å ekspedere resepter hvis de ikke har kommet à jour med at legen har gyldig lisens.

Friske og kompetente legers vurderinger må tas mer alvorlig. Ugyldiggjøring av deres avgjørelser er grovt diskriminerende. Hva med medisinske attester, sakkyndige

\section{«Friske og kompetente legers vurderinger må tas mer alvorlig»}

uttalelser og rapporter? Blir alle disse faglige vurderingene strøket når vedkommende lege dør eller når en eldre kollega $i$ ettertid får aldersbestemt inndragelse av lisens? Kolleger som både fyller faglig kompetanse og legale betingelser som leger, kan ikke desavueres ved dødsfall eller ved deres frafall av lisens i ettertid.

Jeg håper Legeforeningen vil ta fatt i problemene og ordne opp med de relevante instanser.

\section{Egill Hansen}

egillh@online.no

Egill Hansen (f. 1929) er pensjonert overlege,

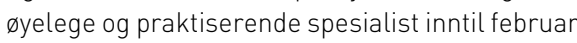
2015 i Oslo

Forfatter har fylt ut ICMJE-skjemaet og oppgir ingen interessekonflikter.

Mottatt 18.11.2015, godkjent 4.12. 2015. Redaktør: Kaveh Rashidi.

Publisert først på nett. 